Marquette University

e-Publications@Marquette

English Faculty Research and Publications

English, Department of

$1-1-2003$

\title{
"Humanizing The Heart," Or Romantic Drama And The Civilizing Process
}

Diane Hoeveler

Marquette University, diane.hoeveler@marquette.edu

Accepted version. European Romantic Review, Vol. 14, No. 1 (2003): 1-5. DOI. (C) 2003 Taylor \& Francis (Routledge). Used with permission. 


\title{
"Humanizing the Heart," Or
}

\section{Romantic Drama and the Civilizing}

\section{Process}

\author{
Diane Long Hoeveler \\ English, Marquette University \\ Milwaukee, WI
}

CHARLES NOIDER, the French dramatist who popularized the Vampire legend on the French stage, once observed that "Romantic drama is nothing but melodrama dressed up in the artificial pomp of lyricism." ${ }^{1}$ Writing in the heyday of Hugo and Dumas, Nodier pointed out that the debt of Romantic dramas to the melodramas of the early nineteenth century was obvious and could be seen in their use of the violent actions of puppets, the picturesque, the heavy reliance on plot, the music, and the excessive theatricality throughout. Bandits and walking ghosts may have faded in popularity by 1830 , but the conventions of melodrama pervaded Romantic drama in Britain, as well as Germany and France, throughout the high Romantic period. However, before one even begins to examine the origins of Romantic drama, one needs to confront the critical truism-propagated for many years-that there simply was no serious or valuable drama written during the Romantic period. The essays collected in this special issue of European Romantic Review represent one of many recent attempts to correct the critical slights that have plagued the scholarly study of Romantic drama. ${ }^{2}$

As someone who reads literature as the master narrative of intellectual history, I see drama as one avenue into understanding the transition that eighteenth-century culture made from an oral-based to a print-based culture. The survival and indeed proliferation of drama

European Romantic Review, Vol. 14 (2003): pg. 1-5. DOI. This article is (c) Routledge and permission has been granted for this version to appear in e-Publications@Marquette. Routledge does not grant permission for this article to be further copied/distributed or hosted elsewhere without the express permission from Routledge. 
on the stage is an interesting case in point. As the newly industrialized, print-based culture chose to define its ideologies in a variety of new genres-the newspaper, the periodical, the novel-the stage was one particularly effective mechanism for holding on to the values of an earlier, oral-based culture. And although much Romantic drama possesses a nostalgic quality, the stage very frequently presented its audiences with new, radical visual displays of social, sexual, and political change. In an era that institutionalized a split between the public and private spheres for men and women-however successfully is a matter of some debate-the stage became a particularly effective public arena in which to perform the vexed issues that an increasingly privatized sphere presented. Hence the proliferation of plays dealing with illegitimacy, courtship, marriage, and property settlements. On the other hand, there were numerous political dramas depicting the evils (as well as the supposed benefits) of racism, colonial expansion, military and naval campaigns, and slavery. There is no doubt that the stage served highly ideological purpose during an era of immense social, political, sexual, and religious transformation. Drama, such as all literature written to express the contorted values of a society in change, became ideologically bifurcated, fissured, presenting both conservative dramas, which sought to shore up the values of an increasingly ineffectual aristocracy, and liberal Jacobin dramas, which attacked the male-dominated artisan culture and showed lower-class women chastising the aristocracy for its greed and hubris.

In order to address a number of private and public issues, the essays in this volume are arranged chronologically and employ a number of different critical methodologies. The first essay, "British Women Playwrights and the Staging of Female Sexual Initiation: Sophia Lee's The Chapter of Accidents (1780)" by Catherine Burroughs, examines the reenactment of hymen-loss as a strategy for erotic arousal, a familiar pattern in the British pornographic traditiona tradition now undergoing extensive analysis thanks to the work of Peter Wagner, Lynda Hunt, Michel Feher, Ian Frederick Moulton, and Bradford K. Mudge. Less familiar, however, are studies that explore mainstream British drama's use of this pattern to comment on the sexual fantasies of late eighteenth-century culture. This essay analyzes Sophia Lee's first and financially lucrative play, The Chapter of Accidents (1780), in order to demonstrate some of the ways in 
which late eighteenth-century British women playwrights introduced pornographic patterns to their work in order to confront-consciously or otherwise-the topic of first-time heterosexual intercourse.

Repeatedly referring to virginity, defloration, and sexual initiation for both comedic-and erotic-effect, The Chapter of Accidents establishes that the equation of childhood innocence with pre-sexual and culturally untainted experiences does not necessarily result in a de-eroticized environment; on the contrary, such an equation can fuel a preoccupation with scenarios in which the sexually uninitiated can be ritually reintroduced to defloration.

The second essay, Daniel O'Quinn's “Hannah Cowley's A Day in Turkey and the Political Efficacy of Charles James Fox," focuses on the first printing of Cowley's controversial orientalist comedy A Day in Turkey; or, The Russian Slaves. The critical furor that deprived the comedy of a Royal audience revolves around the representation of an emigrant French character who is rather unsubtly named " $\mathrm{A}$ La Grecque." His remarks on the contemporary events in France raised questions of political censorship that speak directly to the problem of the theatre's suspect relation not only to hegemonic nationalism, but also to the deep connection between that hegemony and sexual regulation. The complexity of these relationships receives an extraordinary treatment in Cowley's play and this essay explores the interaction of orientalist representation, proto-feminist critique and homophobic Francophobia through a detailed reading of an especially volatile scene in the comedy's final act in which the physicality of theatre becomes the vehicle for political allegory.

The next essay by Aileen Forbes presents an analysis of J oanna Baillie's provocative and significant theory of "sympathetic curiosity," trying to locate it in the intellectual discourses of her day and showing how it anticipates the later nineteenth-century discourse of psychoanalysis. Forbes's essay tightly weaves together the genealogies of sympathy and curiosity, finally focusing on Baillie's last "passion play," Henriquez. Since Henriquez is Baillie's last work to be concerned with the reflective passion of remorse, it resonantly illustrates the idea that Baillie constructs a "proto-psychoanalytic theater."

European Romantic Review, Vol. 14 (2003): pg. 1-5. DOI. This article is (C) Routledge and permission has been granted for this version to appear in e-Publications@Marquette. Routledge does not grant permission for this article to be further copied/distributed or hosted elsewhere without the express permission from Routledge. 
By far the most popular dramatic genre during the Romantic period was melodrama, and my essay attempts to examine the origins of the genre by looking at the writings of Thomas Holcroft, importer of the first work to self-consciously style itself as a "melodrame" on the British stage. By placing Holcroft's The Deserted Daughter, a play written before his extended sojourn in France, against his The Child of Mystery, a decidedly French production, we can, I think, chart almost exactly the swerve that melodrama took as it migrated to Britain. During the eighteenth century the British stage was flooded with works that employed sentimental categories clearly derived from Samuel Richardson, but after the importation and adaptation of Coelina onto the London stage, Romantic drama veers off to become a distinctly hybrid genre, one that splits tragedy and comedy into something that we would recognize today as tragicomedy, an amalgam of "tears and smiles," an uncomfortable mixture of bathos and pathos, snickers and sneers. As always, the most interesting question for the literary historian is: why? This essay frames a number of questions which it then attempts to answer, for instance, why would a culture want to place extreme, hyperbolic-one might say absurd-emotions on public display? And why would dramatists create the most untenable plot situations; most of which we would be charitable to recognize as unrealistic? And even more puzzling, why would lower and middleclass audiences flock to these productions, knowing before the play began that they were soon to witness yet more variations on a few simple themes: the orphan in distress; the machinations of the unmasked greedy villain; the virtue of the mother; and the eventual triumph and restoration of the patriarchal family?

Moving to German Romantic drama, Edwin Block's essay The Broken Jug and "On the Puppet Theater" looks at how Heinrich von Kleist (1777-1811) dramatizes the struggle of Romantic Idealism against the scientism and hyper-rationality of the Enlightenment. As Block observes, in his theoretical writings and in his plays Kleist juxtaposes the idealistic notions of freedom and an Enlightenment nightmare suspicion of determinism, and the result are works rich in ambiguity. A look at Kleist's essay "On the Puppet Theater" and his comedy The Broken Jug illustrates this tension as it also highlights the perennial appeal of drama which, needless to say, has deep philosophical and practical implications for current theatrical practiceand the postmodern world view we seem to be entering. For Block,

European Romantic Review, Vol. 14 (2003): pg. 1-5. DOI. This article is (c) Routledge and permission has been granted for this version to appear in e-Publications@Marquette. Routledge does not grant permission for this article to be further copied/distributed or hosted elsewhere without the express permission from Routledge. 
Kleist's "On the Puppet Theater" and The Broken Jug also inscribe traces of pre-modern antinomies. The puppet theater in the Middle Ages was a popular form, but by the eighteenth century it had become a symbol of the powerlessness that human beings in an Enlightenment determinist world had begun to recognize. Without denying that sinister significance, Kleist also sees the puppet theater as a place of lofty "otherworldliness," where the puppets seem to have a "grace" and lightness of being that provides a tempting image of "freedom." Recognition of the drama's Sophoclean structure undermines as it criticizes the Enlightenment dream of control, for beneath this structure, and transcending Kleist's own somber misgivings about human freedom in an Enlightenment world, the character of Judge Adam remains a mystery, a symbol of the ultimately mysterious human. The corrupt judge is himself the symbol of authoritarian, rational social structure gone awry-that is, operating for the "will to power" of the individual's desires. And the broken jug, besides being a symbol of a young woman's (potentially) lost virtue, is also the symbol of the "container" of state being cracked by the self-centered actions of individuals.

The next essay, Marjean D. Purinton's "Staging the Physical: Romantic Science Theatricalized in T. L. Beddoes's The Brides' Tragedy" explores the intertextuality of science and medicine in Romantic drama, while it also attempts to explain the predominance of gothic and melodrama during the late eighteenth and early nineteenth centuries. Much Romantic drama stages the physical in gothic forms that are significantly redefined by interests in scientific discourses and practices. Purinton calls the strategy for performing the cultural revolution in science "Techno-Gothic," an ideologically charged and melodramatic structure in which disturbing issues and forbidden topics are recontextualized by the intersecting fields of the supernatural and scientific; or the Gothic and technology. The Techno-Gothic relies upon a set of readily available and easily recognizable dramatic (Gothic) conventions that function as interpretations of scientific discourses (technology) at a time when various social critiques and cultural changes were reflected in the theatre. The two most popular and powerful performance manifestations of the Techno-Gothic in Romantic drama appeared as grotesques and ghosts. Purinton's essay examines the drama of Thomas Lovell Beddoes, specifically, The Brides' Tragedy (1822), an contends that Beddoes's plays were shaped by his father's

European Romantic Review, Vol. 14 (2003): pg. 1-5. DOI. This article is (C) Routledge and permission has been granted for this version to appear in e-Publications@Marquette. Routledge does not grant permission for this article to be further copied/distributed or hosted elsewhere without the express permission from Routledge. 
medical work at the Pneumatic Institution in Bristol as well as by his own scientific studies. At Oxford, Beddoes attended anatomical lectures, and later in Germany, he studied medicine, receiving his M.D. in 1831. Friend and physician to Samuel Taylor Coleridge, William Wordsworth, and Robert Southey, Beddoes was also interested in the macabre, the supernatural, and bodily decay. It is not surprising, therefore, to see his drama replete with Techno-Gothic grotesques.

The final essay in the volume, by Alex Dick, revisits the vexed question of Romantic anti-theatricality. Now, this may seem like an out-of-date idea and it is, when taken as the ground for a complete separation of theatre as a public space and drama as a subset of private literature. Romantic theatre studies begins with the premise that the anti-theatrical prejudice is a complete misconception of the importance of theatre in the Romantic period and of the much more difficult and ambiguous questions of the legitimacy/illegitimacy of certain kinds of performances (as argued, for instance, by Jane Moody) and so abandoning anti-theatricality is really the only way to begin. Dick suggests that Romantic anti-theatricality is, nevertheless, a crucial and positive element of Romantic dramaturgy itself. Once we have worked our way through the tangle of representation and power at stake in much of the theatre of the period, including that of the Romantics, he proposes that we are re-confronted with our beginning, the failure of theatre, or anti-theatre. The argument works like this: anti-theatricality is not strictly a policing mechanism (as Julie Carlson contends) just as, Dick proposes, performativity is not liberatory in an opposing sense. Rather, anti-theatricality is a dramaturgy, one involving space, time, convention, dialogue, and movement that demonstrates the tendency of supposedly liberational gestures to become mechanisms of control and thus to collapse on their own contradictory logic. This contradiction, moreover, is inherent in the logic of capitalism; which is where this notion of anti-theatricality confronts the mandate of much Romantic period theatre politics and its historicist defense in criticism today. Dick's contention is that the object of this negative, Romantic performance is the elucidation of something that theatre cannot stage; a kind of metaphysical truth about the social world outside of the realm of capital; and thus theatre becomes a contradiction of itself, unmimetic, as it were, a theatre that is not theatre. As such, this performed anti-theatricality becomes in itself a critique of the opposition between legitimacy and illegitimacy,

European Romantic Review, Vol. 14 (2003): pg. 1-5. DOI. This article is (c) Routledge and permission has been granted for this version to appear in e-Publications@Marquette. Routledge does not grant permission for this article to be further copied/distributed or hosted elsewhere without the express permission from Routledge. 
since the two are staged in such a way that they ironically collapse on each other. The point is that staging this collapse is precisely what certain playwrights (i.e., Baillie, Byron, and Beddoes) and theorists (Coleridge, Lamb, and others) want to do. This is also why, he suggests, so much Romantic theatre is obsessed with death-death is precisely what cannot be staged without failing to be staged; and so the impossibility of death (in capitalism, specifically) becomes the target of a bizarre negative staging. Hence, the answer to the riddle of the mysterious ending of Manfred ("it is not so difficult to die") is that Manfred does not die; he gets up and bows with amazing epistemological consequences for us. Anti-theatricality is not a reaction to the failure of theatre to represent certain things; it is, rather, a theatrical experiment into the nature of representation itself that must fail in order to work. Working with ideas that have been offered recently by Jeff Cox and Michael Simpson, though from different perspectives and to slightly different ends, Dick's model is also drawn from notions of performance in continental and analytical philosophy, so essentially what he offers is a philosophical alternative to the empirical methods usually employed in Romantic theatre criticism.

An overview of the British Women Playwrights around 1800 project concludes the volume. Michael Eberle-Sinatra and Thomas Crochunis discuss some of the problems, challenges, and unique opportunities that have arisen as they have placed the dramas of British women playwrights in cyberspace. Their pioneering work in cyberspace offers us a vision of what could very well be the future for studies of Romantic drama.

Romantic drama is currently undergoing a critical renaissance, and this issue of European Romantic Review hopes to contribute to that rebirth in its own modest way. Thanks are due in no small measure to Fred Burwick for his invitation to produce this volume, and for his generous support and wise counsel throughout.

\section{NOTES}

${ }^{1}$ Nodier quoted in Frank Rahill, The World Melodrama (University Park; Penn State Press, 1967), 69. Nodier's attitude continued to hold sway over critical opinion for more than 150 years. Consider, for instance, Terry Otten who titles his study of Romantic drama The Deserted

European Romantic Review, Vol. 14 (2003): pg. 1-5. DOI. This article is (c) Routledge and permission has been granted for this version to appear in e-Publications@Marquette. Routledge does not grant permission for this article to be further copied/distributed or hosted elsewhere without the express permission from Routledge. 
Stage: The Search for Dramatic Form in Nineteenth-Century England. Otten's approach is typical of earlier critical studies in its emphasis on canonical poets' works, in this case Percy's Shelley's The Cenci and Byron's Cain and Werner. Even The Borderers, however, was not being seriously considered in 1972. Indeed, Otten begins his study by comparing himself to a defense lawyer for Benedict Arnold on trial before the Daughters of the American Revolution: "Never have so many major authors contributed so little to the history of English drama. Despite the fact that every major nineteenth-century poet wrote dramas and almost all of them condemned the current stage, not one could rescue the theater from senile plots, pseudo-Elizabethan techniques, melodramatic claptrap, stock characterizations, and bombastic language" (3).

2 The critical resuscitation of Romantic drama has taken place over the last twenty years and largely in conference venues or special issues of journals, such as this one. For instance, see Richard Allen Cave, ed. The Romantic Theatre: An International Symposium (New York: 1986); The Borderers: A Forum, Studies in Romanticism 27 (1988); the special issue of Texas Studies in Literature and Language 38 (1996) as well as TSLL 41 (1999), which reprints papers presented at the University of Texas symposium "Romantic Drama in Place:

Geography, Scene, Milieu," which also produced Shelley's Prometheus Unbound. Byron's Sardanapalus was staged at Yale University in 1990, while a special session on Romantic drama was held concurrently with the North American Society for the Study of Romanticism conference, University of Western Ontario, London, Ontario, August 2002.

European Romantic Review, Vol. 14 (2003): pg. 1-5. DOI. This article is (C) Routledge and permission has been granted for this version to appear in e-Publications@Marquette. Routledge does not grant permission for this article to be further copied/distributed or hosted elsewhere without the express permission from Routledge. 